\title{
Correction to: A study of variables affecting the consumption of medicinal plant products in urban communities, north of Iran
}

\author{
Hassan Yeganeh ${ }^{1} \cdot$ Raziye Farsi ${ }^{2} \cdot$ Mohammad Rahim Forouzeh $^{2}$. \\ Ardeshir Pournemati ${ }^{2}$. Seyedeh Zohreh Mirdeilami ${ }^{2}$ \\ Published online: 29 August 2021 \\ (c) Springer Nature B.V. 2021
}

\section{Correction to: Environment, Development and Sustainability https://doi.org/10.1007/s10668-021-01698-1}

The original version of the article unfortunately contained an error in one of the author name. The correct name is Mohammad Rahim Forouzeh.

Publisher's Note Springer Nature remains neutral with regard to jurisdictional claims in published maps and institutional affiliations.

The original article can be found online at https://doi.org/10.1007/s10668-021-01698-1.

Hassan Yeganeh

yeganeh@gau.ac.ir

1 Faculty of Range and Watershed Management, Agricultural Sciences and Natural Resources University, Gorgan, Iran

2 Agricultural Sciences and Natural Resources University, Gorgan, Iran 